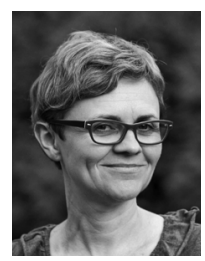

Natasza Szutta •

\title{
WPROWADZENIE, \\ CZYLI O CO CHODZI \\ W DYSKUSJI NAD MORALNYM \\ CHARAKTEREM
}

Spis treści

I. Założenia współczesnej etyki cnót

2. Sytuacjonistyczna krytyka etyki cnót

3. W obronie globalnych dyspozycji i cnót

4. Obrona praktycznej mądrości

Tytuł książki W poszukiwaniu moralnego charakteru może nieco zwieść, sugerując, że jest to publikacja z zakresu edukacji moralnej, w której podane zostaną sposoby doskonalenia moralnego charakteru, między innymi poprzez doskonalenie cnót etycznych. Tymczasem jej problematyka jest bardziej podstawowa, ale o fundamentalnym znaczeniu dla moralnej edukacji. Jest to głos, a właściwie wielogłos w sporze o istnienie moralnego charakteru i jego trwałych dyspozycji; w dyskusji, która aktualnie toczy się na łamach najważniejszych filozoficznych czasopism. Ma charakter interdyscyplinarny, ponieważ jej inspiracją są badania empiryczne przeprowadzone $\mathrm{w}$ ramach psychologii społecznej i kognitywnej. Uczestnikami tej dyskusji są sytuacjoniści, etycy będący pod przemożnym wpływem wyników badań we współczesnej psychologii moralności oraz zwolennicy etyki cnót, przeciw której sytuacjoniści skierowali ostrze swojej krytyki. 


\section{Założenia współczesnej etyki cnót}

Współczesna etyka cnót, zwana także etyką charakteru, jest obecnie jedną z najważniejszych teorii etycznych. Długo zdobywała tę wyróżnioną pozycję - odkąd Elizabeth Anscombe w swoim ważnym artykule skrytykowała niepodzielnie panujące w XX wie$\mathrm{ku}$ teorie etyczne - utylitaryzm i deontologię, wykazując ich trudności i braki, oraz zaapelowała o powrót do Arystotelesowskiej, teleologicznie uzasadnionej, etyki dobrego życia, w której ważną pozycję zajmuje doskonalenie cnót etycznych'. Początki współczesnej odsłony etyki cnót to ostry spór $z$ deontologami i utylitarystami, dotyczący przede wszystkim przedmiotu etyki, kryterium moralnego wartościowania, języka etyki oraz modelu jej uprawiania.

Etycy cnót zwrócili uwagę na to, że w centrum zainteresowań etyków powinien być sprawca, a nie jego czyny. To kondycja moralna sprawców - ich moralny charakter, na który składają się liczne cechy, dyspozycje i postawy moralne, decyduje o sposobie ich zachowania. Dlatego główne pytania, jakie powinni stawiać sobie etycy, powinny brzmieć: „kim powinienem się stać?”, ,jakiego rodzaju cechy i dyspozycje charakteru powinienem uosabiać?". Wszystko to, co dotyczy moralnego podmiotu - intencje, motywy i postawy, które skłaniają sprawcę do określonego działania - jest pierwszorzędne względem działania. Nie tylko pozwala wyjaśnić, dlaczego sprawca tak a nie inaczej postępuje, ale też - jeśli się dobrze je ukierunkuje - gwarantuje regularne, a nie jedynie okazjonalne, moralnie dobre zachowania.

Dla deontologów i utylitarystów głównymi pytaniami etycznymi były: „co sprawca powinien czynić?”, ,jakie czyny są moralnie słuszne, a jakie moralnie niesłuszne?", dlatego koncentrowali się na formułowaniu uniwersalnych zasad, stanowiących łatwe kryterium moralnego wartościowania czynów, oraz procedurach decyzyjnych, które - jeśli są poprawnie zastosowane - pozwalają zawsze, krok po kroku, w sposób racjonalny, poprawnie rozwiązywać moralne

G.E. Anscombe, Modern Moral Philosophy, „Philosophy” 33 (I958), s. I-I9. 
problemy. Ta abstrakcyjność zasad (na przykład utylitarystyczna zasada maksymalizacji szczęścia największej liczby ludzi lub Kantowska zasada uniwersalizacji) i procedur decyzyjnych jest także przedmiotem krytyki, którą w połowie ubiegłego stulecia zapoczątkowali etycy cnót. Działania moralne - jak zauważają dotyczą konkretnych, a nie uniwersalnych sprawców, adresatów i sytuacji. Proponują przyjąć bardziej partykularny - roztropnościowy - punkt widzenia, zgodny z Arystotelesowską definicją cnotliwego działania, które zawsze jest dokonywane „we właściwym czasie, $z$ właściwych przyczyn, wobec właściwych osób, we właściwym celu i we właściwy sposób” ${ }^{2}$. Miarę tego, co „właściwe”, określa mądrość praktyczna (phronesis). Etycy cnót uważają, że człowiek o moralnie dobrym charakterze to ktoś, kto uosabia cnoty etyczne; człowiek cnotliwy to także ktoś posiadający mądrość praktyczną, obejmującą wiedzę moralną, zdobytą w toku bogatego doświadczenia; ktoś, kto wie, co należy czynić, ponieważ przyjmuje odpowiednią postawę wobec adresatów działania, jest wystarczająco zmotywowany i potrafi we właściwy sposób odpowiadać na zaistniałe moralne racje. Cnoty etyczne są trwałymi i nabytymi dyspozycjami usprawniającymi jego moralnie dobre zachowanie. Głównym zadaniem etyki i etyków cnót jest zatem moralna edukacja w kierunku wychowania cnotliwego sprawcy.

W tym celu zamiast uniwersalnych zasad etycy cnót proponują odwołać się do paradygmatycznych wzorców moralnie dobrego charakteru, uosabianych przez tzw. moralnych bohaterów, czy to realnych, czy zapisanych na przykład w heroicznych opowieściach - ludzi „z krwi i kości”, którzy mogą stanowić wyrazisty punkt odniesienia w moralnej edukacji. Ich przykład ma nie tylko uczyć, co jest moralnie dobre, a co złe, ma też jednocześnie pociągać i zachęcać do naśladowania. To ważny afektywny aspekt tej teorii, która nie zatrzymuje się jedynie na uzasadnieniu moralnie słusznych przekonań, ale jednocześnie motywuje do zgodnego $z$ nimi postępowania. Wychodzi poza ramy czysto abstrakcyjnych

2 Arystoteles, Etyka Nikomachejska, tłum. D. Gromska, Warszawa 2007, s. I6-I7 [II06b] (dalej oznaczona skrótem EN; w nawiasach kwadratowych lokalizacja fragmentów w wydaniu krytycznym). 
rozważań w kierunku zachwycania ludzi dobrocią, życzliwością, uczciwością i męstwem. Etycy cnót raczej unikają formułowania uniwersalnych zasad moralnych. W ich miejsce proponują coś na wzór drogowskazów moralnie dobrego postępowania, których treść daje się wyprowadzić na podstawie analizy konceptualnej cnót etycznych. Ich katalogi mogą stanowić rodzaj przewodnika po moralnie dobrym życiu. Uczciwy człowiek to ktoś, kto nie oszukuje, nie kłamie, dotrzymuje obietnic; jest pomocny - nie pozostawia w potrzebie, wrażliwy na krzywdę innych, potrafi się dzielić swoimi dobrami, życzliwy. To ktoś, kto pragnie dobra innych ludzi i nie przeszkadza, tylko wspiera ich w samodoskonaleniu się, w swoim działaniu zawsze bierze pod uwage ich dobro. Te wskazówki do cnotliwego działania są bardzo intuicyjne i nie ma większych trudności z ich rozumieniem. Mogą być łatwo wykorzystywane w codziennym życiu. Pomagają w dokonywaniu moralnie dobrych wyborów, jednocześnie ich nie usztywniają, lecz pozwalają na roztropne dopasowanie do zaistniałych warunków działania.

Etycy cnót ponadto postulują zmianę języka etyki. Deontolodzy, a także niektórzy utylitaryści, posługują się językiem deontycznym, wykorzystując pojęcia powinności, nakazów i zakazów moralnych, które często budzą naturalny sprzeciw i domagają się gruntownego umocowania. Człowiek jest tak psychicznie skonstruowany, że spontanicznie negatywnie reaguje na jakiekolwiek obowiązki i wymagania. Etycy cnót proponują zastąpić język deontyczny językiem aretycznym. W miejsce nakazów i zakazów proponują pojęcia cnót etycznych, jak na przykład uczciwość, prawość, życzliwość, które budzą pozytywne emocje, bo któż nie chciałby być uważany za dobrego człowieka, uosabiającego takie pozytywnie wartościujące cechy, budzące powszechny szacunek i uznanie.

Zmianie języka etyki towarzyszy także propozycja zmiany modelu uprawiania etyki. Etycy cnót nie chcą budować kolejnych teorii etycznych na wzór nowożytnych teorii naukowych, spełniających liczne warunki - uniwersalności, abstrakcyjności czy formalności itp. Uważają, że życie moralne jest zbyt złożone, by można je uporządkować, budując uniwersalną teorię. Są takie problemy etyczne, które mają charakter moralnych dylematów lub nieusuwalnych konfliktów, dla których moralnie dobre rozwiąza- 
nie nie istnieje. Można je, co najwyżej, rozstrzygać, jednak żadna opcja nie może zadowalać moralnie dobrego sprawcy. Mądrościowy (fronetyczny) charakter etyki cnót także przemawia za podejściem antyteoretycznym, w którym nie ma wiele miejsca na uniwersalne rozwiązania. W decyzjach moralnych należy zawsze brać pod uwagę konkretną sytuację moralną - kondycję moralną sprawcy i adresata działania oraz rodzaj wyzwania, przed jakim stoją. Wychowanie w cnotach etycznych ma zagwarantować umiejętność dokonywania właściwych wyborów w sytuacjach zarówno niecodziennych, trudnych, problematycznych, jak i codziennych, które nie wymagają jakiejś szczególnej refleksji moralnej i można polegać na utrwalonych schematach postępowania ${ }^{3}$.

Tak rozumiana propozycja uprawiania etyki tchnęła w XX-wieczny dyskurs etyczny nowego ducha, rozpoczęła wiele dyskusji między zwolennikami etyki cnót a utylitarystami i deontologami.

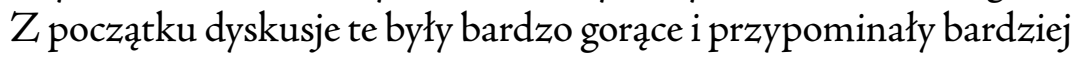
walkę wrogich obozów niż konstruktywną debatę metaetyczną, jednak po latach zaowocowały zbliżeniem poglądów, przynajmniej w niektórych kwestiach. Utylitaryści i deontolodzy doszli do przekonania, że podmiotowy aspekt etyki, którego wagę podnosili etycy cnót (wszystko, co dotyczy kondycji moralnej sprawcy - intencje, motywy, dyspozycje), jest równie ważny jak deliberacje nad słusznością i niesłusznością określonych typów działania. Śladem Johna Stuarta Milla i Immanuela Kanta, którzy sporo pisali o cnotach etycznych, przypisując im istotne znaczenie, współcześni zwolennicy etyki Kantowskiej i utylitaryści zaczęli formułować teorie cnót w ramach utylitaryzmu i deontologii. I choć przypisują oni cnotom wyłącznie instrumentalny charakter, to jednak doceniają ich rangę $\mathrm{w}$ moralnie słusznym $\mathrm{d} z i a ł a n i u^{4}$.

3 Ogólną charakterystykę etyki cnót oraz dyskusję pomiędzy jej zwolennikami a dentologami i utylitarystami szerzej zaprezentowałam w swojej książce Współczesna etyka cnót. Projekt nowej etyki?, Gdańsk 2007. Na temat statusu współczesnej etyki cnót względem deontologii i utylitaryzmu pisałam w artykule Status współczesnej etyki cnót, „Diametros - Internetowe Czasopismo Filozoficzne IF UJ" I (2004), s. 70-84.

4 Warto w tym miejscu wspomnieć o pracach Onory O'Neill, Roberta Loudena, Petera Railtona, Rogera Crispa, Julii Driver. 
Tę zmianę charakteru dyskusji i docenienie znaczenia podmiotowego aspektu moralnego działania przez utylitarystów i deontologów można uznać za sukces etyków cnót, po którym nastąpił gwałtowny wzrost znaczenia proponowanej przez nich koncepcji etyki, widoczny w rozwoju licznych etyk stosowanych, uprawianych w jej duchu. Tak jak w połowie poprzedniego stulecia każdy niemal artykuł pisany przez jej zwolenników i propagatorów zaczynał się od narzekania na zastąpienie w nowożytnej etyce języka aretycznego językiem deontycznym i nieobecność pojęć cnót $\mathrm{w}$ dyskursie etycznym, obecnie daje się odczuwać nawet pewien nimi przesyt, ponieważ język aretyczny przeniknął nie tylko do licznych dyscyplin filozoficznych, ale też innych, publicznych dziedzin życia. W duchu etyki cnót uprawia się niemal wszystkie etyki praktyczne (m.in. etykę społeczną i polityczną, etykę wychowania, etykę biznesu, bioetykę i etykę medyczną). Także teoretycy poznania coraz częściej rozprawiają o cnotach epistemicznych, czyniąc z nich odrębny temat dociekań. Język aretyczny jest także obecny w różnych mediach. Dziennikarze na co dzień używają go w debatach nad różnymi problemami społecznymi i politycznymi, coraz częściej słyszy się o konieczności doskonalenia cnót obywatelskich, by społeczeństwo obywatelskie rosło w siłę. Pojęcie „cnoty" nie jest już archaiczne, zapomniane i rzadkie - jak twierdzili jego propagatorzy. Wszystko to wraz z bardzo bogatą literaturą na temat cnót, moralnego charakteru i etyki cnót, jako odrębnego podejścia w etyce, składa się na niepodważalny sukces etyków cnót.

Przełom XX i XXI wieku można zatem z jednej strony uznać za szczytowy moment rozwoju etyki cnót, ponieważ w tym czasie powstało najwięcej monografii jednoautorskich, prezentujących dopracowane ujęcia koncepcji etycznych, skoncentrowanych na kształtowaniu moralnego charakteru i etycznych cnót, które znalazły wiele zastosowań w etyce praktycznej. Widać to szczególnie w kodeksach etyk poszczególnych zawodów, choćby tam, gdzie język deontologiczny powoli zostaje dopełniany, a nawet wypierany przez język aretologiczny (m.in. kodeks zawodu nauczyciela, pielęgniarki i położnej). Mówi się nawet, że za sprawą etyków cnót dokonała się zmiana paradygmatu w uprawianiu etyki - $z$ etyki skoncentrowanej na czynie na etykę skoncentrowaną na moralnym 
sprawcy $^{5}$. Z drugiej strony to początek bardzo poważnej krytyki, owocującej kolejną gorącą dyskusją wokół psychologii moralności, na której ufundowana jest etyka cnót. Dyskusją, która jest chyba nawet poważniejsza niż ta, przeprowadzona wcześniej pomiędzy etykami cnót a utylitarystami i deontologami. Choć ostrze krytyki sytuacjonistycznej jest skierowane na etykę cnót, to pośrednio dotyka także innych teorii etycznych, ponieważ w świetle tej krytyki moralny sprawca nie jawi się jako autonomiczny podmiot swoich moralnych decyzji, ale jako bierna istota, popychana do różnych - czasem dobrych, czasem złych - zachowań przypadkowymi, sytuacyjnymi czynnikami; ponadto w swoim działaniu kieruje się licznymi automatycznymi procesami, których nie jest nawet $\mathrm{w}$ stanie do końca sobie uświadamiać. Jeśli rzeczywiście badania empiryczne - jak twierdzą sytuacjoniści - jednoznacznie potwierdzają taki obraz funkcjonowania ludzkich istot, to zwolennicy wszystkich najważniejszych teorii etycznych, biorący udział we współczesnym dyskursie etycznym, mają poważny kłopot.

\section{Syłuacjonistyczna kryłyka etyki cnół}

Sytuacjoniści - etycy inspirowani badaniami przeprowadzonymi w ramach psychologii społecznej i kognitywnej - rozpoczęli swoją krytykę od ataku na etykę cnót i samą kategorię cnoty - rozumia-

5 Liczbę publikacji powstałych w ramach etyki cnót trudno już zliczyć. Wśród monografii jednoautorskich warto wymienić: A. MacIntrre, Dziedzictwo cnoty, tłum. A. Chmielewski, Warszawa 1996; M. Nussbaum, The Fragility of Goodness: Luck and Ethics in Greek Tragedy and Philosophy, Oxford I986; M. Slote, Goods and Virtues, Oxford 1989; tenże, From Morality to Virtue, Oxford 1995; tenże, Morals from Motives, Oxford 200I; N. Sherman, The Fabric of Character: Aristotle's Theory of Virtue, Oxford 1989; taż, Making a Necessity of Virtue: Aristotle and Kant on Virtue, Cambridge 1997; J. Annas, The Morality of Happiness, Oxford 1993; R. Audi, Moral Knowledge and Ethical Character, Oxford-New York 1997; R. Hursthouse, On Virtue Ethics, Oxford I999; C. Swanton, Virtue Ethics: A Pluralistic View, Oxford 2003; R. Adams, A Theory of Virtue: Excellence in Being for the Good, Oxford 2006. 
nej jako nabyta i trwała dyspozycja do moralnie dobrego działania. Powołując się na liczne eksperymenty i dane historyczne, próbowali udowodnić, że charakter moralny i cnota w takiej formie, w jakiej rozumieją ją etycy cnót, w rzeczywistości nie istnieją, dlatego nie mogą mieć wpływu na ludzkie zachowanie. Gilbert Harman, John Doris, Maria Merritt, Peter Vranas uważają, że globalistycznie rozumiane cnoty, czyli te, które przejawiają się stałym, spójnym i zintegrowanym pod względem moralnym zachowaniem, są empirycznie nieadekwatne. To znaczy, że żadne badania empiryczne ich nie ujawniają. Przeciwnie, większość danych eksperymentalnych i historycznych pokazuje, że na nasze zachowanie największy wpływ ma sytuacja, w jakiej zostaliśmy postawieni ${ }^{6}$. Przypisywanie ludziom cnót etycznych i ocenianie ich zachowania w odwołaniu do nich (mówi prawdę, ponieważ jest prawdomówny; kłamie, ponieważ jest kłamczuchem) jest popełnianiem fundamentalnego błędu atrybucji, na który już od lat zwracają uwagę psychologowie społeczni.

Sytuacjonistyczna krytyka nawiązuje do dyskusji, która w połowie poprzedniego stulecia, właśnie wtedy, gdy na gruncie etyki Elisabeth Anscombe proponowała powrót do Arystotelesowskiej etyki cnót, rozgorzała na gruncie psychologii. Wówczas właśnie psychologowie społeczni bardzo ostro skrytykowali psychologię osobowości, dyscyplinę o ustalonym już statusie akademickim, potwierdzonym latami obecności na uniwersytecie. Według jej założeń każdy człowiek posiada określoną osobowość, na którą

6 G. Harman, Moral Philosophy Meets Social Psychology: Virtue Ethics and the Fundamental Attribution Error, „Proceedings of the Aristotelian Society”, New Series 99 (I999), s. 3I6-33I; tenże, No Character or Personality, „Business Ethics Quarterly” I3 (2003), s. 87-94; tenże, Skepticism about Character, „Ethics” I3 (2009), s. 235-242; J.M. Doris, Lack of Character, Cambridge 2002; P.B.M. VRanas, The Indeterminacy Paradox: Character Evaluations and Human Psychology, „Nous” 39 (2005), s. I-42; tenże, Against Moral Character Evaluations: The Undetectability of Virtue and Vice, "Ethics” I3 (2009), s. 213-233; M.W. Merritt, Aristotelean Virtue and the Interpersonal Aspect of Ethical Character, "Journal of Moral Philosophy" 6 (2009), s. 23-49; M.W. Merritt, J.M. Doris, G. Harman, Character [w:] J.M. Doris i in. (eds.), Moral Psychology Handbook, Oxford 2010, s. 355-40I.

7 L. Ross, R.E. Nisbett, The Person and the Situation. Perspectives of Social Psychology, New York 199I, s. 88-9I. 
składają się różne cechy, których rozpoznanie pozwala w wiarygodny sposób przewidywać jego przyszłe zachowania. Psychologowie społeczni, walcząc o swoją akademicką pozycję, zakwestionowali zarówno główną tezę psychologii osobowości, przeciwstawiając jej teorię wpływu społecznego, według której o sposobie ludzkiego zachowania znacznie bardziej decydują zmienne sytuacyjne niż osobowościowe, jak i metody, którymi psychologia osobowości się posługuje (testy osobowości, kwestionariusze), ujmujące jedynie pierwszoosobową perspektywę badanego, określając je „metodą papierowo-ołówkową". Przeciwstawili tym metodom badania eksperymentalne, które pozwoliły przekroczyć pierwszoosobową perspektywę i obserwować badanych z perspektywy zewnętrznej, gdy są poddawani różnym, nie zawsze uświadamianym sobie wpływom społecznym.

Na gruncie psychologii ten spór już nieco przebrzmiał i wyrażane poglądy stały się znacznie mniej spolaryzowane. Wyraźne przeciwstawienie wpływu osobowości wpływowi sytuacji zostało zastąpione teoriami interakcjonistycznymi, w których dostrzega się wagę obu czynników - osobowościowych i sytuacyjnych, które nieustannie na siebie oddziałując, wpływają na nasz sposób zachowania ${ }^{8}$. Analogiczna dyskusja na gruncie etyki pomiędzy sytuacjonistami, odwołującymi się wprost do wyników badań psychologów społecznych, a etykami cnót, którzy w założeniach proponowanej przez siebie teorii nawiązują do określonej i trwałej struktury osobowości, w zasadzie dopiero niedawno się zaczęła, co między innymi przejawia się w polaryzacji stanowisk, gorącej atmosferze i szybkiej wymianie argumentów.

Wydawałoby się, że etycy cnót mogliby w punkcie wyjścia zakończyć ten spór, wskazując na normatywny charakter cnoty i etyki cnót. Wystarczyłoby powołać się na starą etyczną zasadę, wedle której nie można powinności działania wyprowadzać z opisu faktów, których źródłem byłyby dane eksperymentalne i historyczne, przywoływane przez sytuacjonistów. Jednak sytuacjoniści, świadomi takiej możliwej strategii obrony, powołując się na

8 B. Krahé, Situation Cognition and Coherence in Personality: An Individual-Centred Approach, Cambridge I990, s. I7-45. 
inną równie ważną zasadę: „żadna powinność - norma moralna - nie może lekceważyć ludzkiej kondycji, czyli możliwości działania"', dali do zrozumienia etykom, że wyniki badań psychologów moralności muszą być brane pod uwagę w formułowaniu norm i kreśleniu ideałów moralnych. Zarzut sytuacjonistów kierowany pod adresem etyków cnót głosi, że cnoty i cnotliwy charakter, które skutkowałyby moralnie dobrym działaniem, są niemożliwe do osiągnięcia $z$ bardzo podstawowego powodu - człowiek zupełnie inaczej funkcjonuje w świecie, niż zakładał Arystoteles, a wraz za nim współcześni etycy cnót ${ }^{10}$.

$\mathrm{Na}$ ludzkie zachowanie znacznie większy wpływ mają czynniki zewnętrzne niż jakiekolwiek dyspozycje i cechy charakteru, do tego stopnia, że można nawet powątpiewać, czy takie globalnie ujęte cechy i dyspozycje charakteru, przejawiające się spójnym z nimi, stałym i zintegrowanym pod względem wartości zachowaniem, w ogóle istnieją ${ }^{11}$. Liczne dane eksperymentalne potwierdzają bowiem przemożne skutki wpływu autorytetu ${ }^{12}$, roli społecznej ${ }^{13}$, pośpiechu ${ }^{14}$,

9 J.M. Doris, Lack of Character..., dz. cyt., s. II2.

10 Tamże, s. 92-106.

11 Globalne ujęcie cnót etycznych zostało sformułowane przez Johna Dorisa, ale oddaje główne założenia etyków cnót. Cnotliwy człowiek - np. uczciwy - działa spójnie $z$ cnotą uczciwości w różnych, nawet niesprzyjających jej okolicznościach. Jego działania o takim charakterze są stałe, a nie jedynie okazjonalne. Ponadto uosabia on także inne zintegrowane $z$ nią pod względem wartości cnoty, np. prawdomówność, sprawiedliwość, dotrzymywanie obietnic. Przypisywanie komuś cnotliwego charakteru zakłada, że jego zachowanie spełnia te warunki. Por, tamże, s. 22-23.

12 W eksperymencie Stanleya Milgrama około 60\% badanych przez nikogo i przez nic nieprzymuszanych, wbrew swoim przekonaniom, wielokrotnie raziło prądem o napięciu od I5 do 420 woltów (każdy kolejny wstrząs był o I5 woltów silniejszy od poprzedniego) niewinnego człowieka, który już od 330-woltowego wstrząsu nie dawał żadnych oznak życia; S. Milgram, Posłuszeństwo wobec autorytetu, tłum. M. Hołda, Kraków 2008.

13 P.Zimbardo po kilku dniach musiał przerwać swój więzienny eksperyment, ponieważbadani tak dalece utożsamili się ze swoją rolą, że dochodziło do aktów werbalnej, psychicznej i fizycznej przemocy, wbrew regulaminowi; P. Zimbardo, Efekt Lucyfera. Dlaczego dobrzy ludzie czyniq zło?, tłum. A. Cybulko i in., Warszawa 2010.

14 J.M. Darley i C.D. Batson w eksperymencie, w którym wzięli udział studenci seminarium teologicznego, pragnący w przyszłości głosić Ewangelię, wykazali, że w sytuacji bardzo prozaicznego braku czasu można nie zauważyć osoby potrzebującej pomocy (ok. 60\% badanych); J.M. Darley, C.D. Batson, 
nastroju ${ }^{15}$ itp. na nasze zachowanie, natomiast dane historyczne potwierdzają wielką siłę wpływu społecznego w czasie różnych niepokojów społecznych, rewolucji i wojen ${ }^{16}$. Dlatego zalecanie poprawy kondycji moralnej przez doskonalenie cnót etycznych w perspektywie tych badań nie ma najmniejszego sensu, bo musi skończyć się fiaskiem. Można co najwyżej ukształtować „cnoty lokalne” (local virtue), mające bardzo wąski charakter, przypisany konkretnym sytuacjom, $z$ którymi powiązane jest określone zachowanie $^{17}$. W miejsce edukacji charakteru, na którą szczególny nacisk kładą etycy cnót, proponują odpowiednią politykę społeczną, która ma przejawiać się przemianą warunków społecznych wpływających na ludzkie zachowanie w kierunku wzmacniania czynników popychających ludzi do dobrych moralnie zachowań i eliminowanie tych skłaniających ich do zachowań moralnie $z \nmid y c h{ }^{18}$.

From Jerusalem to Jericho. A Study of Situational and Dispositional Variables in Helping Behavior, "Journal of Personality and Social Psychology” 27 (I973), s. 100-108.

15 A.M. Isen i P.F. Levin w swoim eksperymencie pokazały, jak mały niezauważalny czynnik (znalezienie grosika) może wpłynąć na nastrój i zachowania pomocowe. Badani, którzy znajdowali grosik lub dostali ciasteczko, znacznie chętniej pomagali niż ci, którzy niczego nie znaleźli. A.M. Isen, P.F. Levin, Effect of Feeling Good on Helping: Cookies and Kindness, ,Journal of Personality and Social Psychology" 2I (I972), s. 384-388.

16 H. Walzer, Sprawcy. Dlaczego zwykli ludzie dokonuja masowych mordów, tłum. M. Kurkowska, Warszawa 2010.

17 J.M. Doris, Lack of Character..., dz. cyt., s. II5-II6. Ktoś może cechować się „odwagą do żeglowania po niebezpiecznych wodach z przyjaciółmi” (sailing-in-rough-weather-with-one's-friends courageous) albo „współczuciem, gdy znalazłszy monetę, pomaga pozbierać komuś rozrzucone dokumenty" (dime -finding-dropped-paper compassionate), ale zarazem być tchórzem, gdy żegluje po niebezpiecznych wodach z obcymi ludźmi, i bez odrobiny współczucia, gdy nie znajduje monety poprawiającej mu nastrój. Więcej na temat lokalnych cnót pisze Rachana Kamtekar w swoim artykule O stawaniu się dobrym człowiekiem: waskie dyspozycje i stabilność cnoty, który został zamieszczony w niniejszym tomie (s. 73-I02).

18 J.M. Doris, Lack of Character..., dz. cyt., s. I25-I27; G. Harman, Moral Philosophy..., dz.cyt. 


\section{W obronie globalnych dyspozycji i cnót}

W pierwszej fazie dyskusji sytuacjonistyczna krytyka etyki cnót koncentrowała się na samej kategorii cnoty i moralnego charakteru, którego istnienie w jego globalistycznym rozumieniu zakwestionowali sytuacjoniści. Obrońcy etyki cnót przyjęli dwie strategie.

Pierwsza polegała na wykazaniu, że wyniki badań w obrębie psychologii nie pozwalają na wyprowadzenie tak radykalnego wniosku, jakoby cnoty i cnotliwy charakter były empirycznie nieadekwatne; co najwyżej, że są rzadkie, czego nigdy nie kwestionował ani Arystoteles, ani współcześni etycy cnót. W ramach tej linii argumentacyjnej można mnożyć zarzuty metodologiczne pod adresem eksperymentów, których wyniki stały się podstawą wniosków sytuacjonistów (wielkość i reprezentatywność grupy badawczej, adekwatność metody eksperymentalnej w badaniach nad charakterem, nienaturalność sytuacji eksperymentalnej itp.). Można także zwracać uwagę, że w trakcie tych badań eksperymentalnych zawsze znajdowali się ci „sprawiedliwi”, którzy choć stanowili mniejszość (ok. 30\%), opierali się sile sytuacyjnego wpływu (odmawiali kontynuowania eksperymentu - Milgram, pomagali osobie potrzebującej - Darley, Batson).

Druga strategia zmierzała w kierunku wykazania, że sytuacjonistyczna krytyka odnosi się jedynie do prymitywnej koncepcji cnoty, która nie ma zwolenników wśród etyków cnót, choć jest dość często przyjmowana przez jej przeciwników. Ze sposobu, $\mathrm{w}$ jaki sytuacjoniści argumentują przeciw istnieniu cnót etycznych, można wnioskować, że ujmują je wyłącznie behawioralnie - przypisując konkretnym cnotom określone sposoby zachowania (osoba pomocna zawsze pomaga, a osoba prawdomówna zawsze mówi prawdę). Etycy cnót, natomiast, cnotę rozumieją w sposób bardziej złożony - jako zespół kognitywnych i afektywnych procesów, które mogą się behawioralnie przejawiać na różne sposoby. A to oznacza, że o posiadaniu tak rozumianej cnoty nie da się orzekać jedynie na podstawie badań eksperymentalnych, ponieważ one zatrzymują się jedynie na obserwacji ludzkich zachowań i nie 
wnikają w wewnętrzne (kognitywne i afektywne) stany badanych. Zwrócono też uwagę, że mądrość praktyczna (phronesis), której nie bez powodu przypisuje się w etyce cnót bardzo ważną rolę, jest wrażliwa na kontekst sytuacyjny działania (to ona odpowiada za poszukiwanie najwłaściwszych sposobów reagowania na zaistniałą sytuację moralną - „trafianie w środek pomięd zy skrajnościami”), dlatego zarzucanie etykom cnót, że pomijają społeczny kontekst moralnego działania, wydaje się zupełnie bezpodstawne. Człowiek cnotliwy to ktoś, kto biorąc pod uwagę sytuacyjny kontekst, dopasowuje doń właściwe działanie, a nie jedynie biernie się poddaje społecznym wpływom, jak twierdzą sytuacjoniści.

Na gruncie psychologii społecznej można znaleźć wiele teorii, $\mathrm{w}$ ramach których da się obronić istnienie globalnie rozumianych dyspozycji charakteru, ujętych jako procesy kognitywno-afektywne, które mają swoje odzwierciedlenie w wewnętrznie spójnym, charakterystycznym dla konkretnej jednostki zachowaniu. W dyskusji wielu obrońców etyki cnót - jak na przykład Nancy Snow ${ }^{19}$ i Dan Russell ${ }^{20}$ - odwołuje się do koncepcji kognitywno -afektywnego systemu osobowości Waltera Mischela, który broni istnienia względnie spójnej struktury osobowości każdego indywidualnego człowieka. $\mathrm{Na}$ tak rozumianą osobowość składa się powiązana ze sobą sieć różnych procesów mentalnych, takich jak sposób widzenia i interpretowania sytuacji, w jakiej przychodzi konkretnej jednostce działać, połączony $z$ jej celami, wartościami, uczuciami, emocjami, przekonaniami i planami samoregulacji $^{21}$. W tym ujęciu nie mówi się już o czynnikach sytuacyjnych jako wywierających wpływ na sposób zachowania konkretnej osoby, tylko o charakterystycznym dla niej sposobie ich widze-

19 N. Snow, Virtue and the Social Intelligence. An Empirically Grounded Theory, New York 2010. Por. jej artykuł w niniejszym tomie (s. 35-73).

20 D.C. Russell, Practical Intelligence and the Virtues, Oxford 2009. Por. jego artykuł w niniejszym tomie (s. 29I-329).

21 W. Mischel, Y. Shoda, A Cognitive-Affective System Theory of Personality: Reconceptualizing the Invariances in Personality and the Role of Situations, „Psychological Review" I02 (I995), s. 246-268; Y. Shoda, S.L. Tiernan, W. Mischel, Personality as a Dynamical System: Emergence of Stability and Distinctiveness from Intra- and Interpersonal Interactions, „Personality and Social Psychology Review" 6 (2002), s. 316-325. 
nia - konstruowania, które skutkuje określonym zachowaniem. Nasze reakcje na konkretne zdarzenia czy sytuacje są wypadkową układu wszystkich interakcji pomiędzy tymi czynnikami, dlatego z perspektywy zewnętrznego obserwatora mogą wydawać się niespójne, co mogłoby świadczyć, że sterują nim przypadkowe, sytuacyjne zmienne. Tak właśnie argumentują sytuacjoniści, wykazując stosunkowo niski obserwowany stopień korelacji pomiędzy zachowaniami różnych ludzi w różnych sytuacjach, i wyprowadzają wniosek, że nie istnieje nic takiego jak globalnie rozumiany charakter i jego dyspozycje ${ }^{22}$.

Jednak zdaniem Mischela osobowość każdego indywidualnego człowieka przejawia się w działaniu zgodnym z określonymi dla niego behawioralnymi wzorcami (behavioral signature), które można wyrazić w formule ,jeśli..,, to”, przy czym ,jeśli” oznaczają

22 Sytuacjoniści w swojej argumentacji powołują się na badania korelacyjne, przeprowadzone przez T. Newcomba (I929), H. Hartshorne'a i M.A. Maya (1928), które polegały na obserwacji dzieci pod względem spójności ich zachowań $z$ określonymi cechami (Newcomb - z ekstrawersją; H. Hartshorne, M.A. May $-z$ uczciwością). Badacze skrupulatnie notowali ich zachowania w różnych kontekstach sytuacyjnych. Ogólny stopień korelacji między zachowaniami badanych odpowiadającymi badanej cesze okazał się bardzo niski, jednak przy uwzględnieniu czynnika sytuacyjnego wzrastał; w określonych kontekstach sytuacyjnych dzieci zachowywały się spójnie z określoną cechą (ściągały na teście, ale nie w trakcie odrabiania zadań domowych).

W dyskusji na temat spójności zachowania należy odróżnić wewnątrzosobową spójność zachowania (intrapersonal consistency) od pomięd zysytuacyjnej spójności (intersituational consistency). Badania korelacyjne, na które powołują się sytuacjoniści, uwzględniają jedynie spójność pomięd zysytuacyjną - spójność zachowania całej badanej grupy w różnych sytuacjach i stopień korelacji pomiędzy zachowaniami całej badanej populacji, który okazywał się bardzo niski, co wykorzystywano w dyskusji jako empiryczny dowód na większe znaczenie wpływu sytuacji niż charakteru moralnego badanych; por. L. Ross, R.E. Nisbet T, The Person and the Situation..., dz. cyt., s. 96-97, 465-466. Natomiast badania Mischela i Shody koncentrowały się na wewnętrznej spójności konkretnego badanego, dodatkowo uwzględniały indywidualny sposób intepretowania (konstruowania) przez badanego sytuacji eksperymentalnej, w której podejmował działania. Okazało się, że ten sposób podejścia, uwzględniający pierwszoosobową perspektywę badanych, pozwalał na obserwowanie znacznie wyższego stopnia spójności ich zachowania. W. Mischel, Y. Shoda, A Cognitive-Affective System Theory of Personality..., dz. cyt., s. 246-268; Y. Shoda, S.L. Tiernan, W. Mischel, Personality as a Dynamical System..., dz. cyt., s. 316-325. 
charakterystycznie dla sprawcy skonstruowane sytuacje, a „to" sposób jego zachowania. Ów model jest poparty wieloma badaniami empirycznymi - wieloletnimi i systematycznymi obserwacjami na stosunkowo licznych grupach badawczych. Co prawda Mischel nie badał ludzi pod względem posiadania przez nich etycznych cnót, ale jego koncepcja osobowości może być przez etyków cnót wykorzystywana jako neutralny moralnie fundament, na którym może wspierać się etyka cnót. Jego badania potwierdzają, że ludzie są „jacys”, „określeni”, posiadający trwałe cechy i dyspozycje charakteru, ujęte w kategoriach kognitywno-afektywnych, a nie jedynie behawioralnych, które można kształtować. Są one własnościami sprawców, a nie sytuacji, jak sugerują sytuacjoniści. Dlatego Peter Vranas myli się, głosząc „paradoks nieokreśloności”, zgodnie z którym ludzie nie są ani dobrzy, ani źli, ani nawet po środku, tylko nijacy, popychani do działania przez zewnętrzne sytuacyjne zmien$n^{23}$. Być może tradycyjnie rozumiane cechy i dyspozycje charakteru są zbyt ogólne i mało zdywersyfikowane, by można adekwatnie scharakteryzować poszczególne jednostki, uwzględniając wszystkie indywidualne różnice, zważywszy że określone cechy można posiadać $\mathrm{w}$ różnym stopniu, w odniesieniu do różnych dziedzin życia (np. być cierpliwym i pracowitym w obrębie tego, co mnie interesuje i jest dla mnie wartościowe, ale już nie w odniesieniu do tego, co mnie nudzi i czego nie cenię). Ta złożoność naszej osobowości wcale nie musi prowadzić do wniosku, że ludzie są nijacy, tylko ich charakterystyka może być bardziej złożona, niż zakładają to tradycyjne taksonomie cech i dyspozycji charakteru.

Wykorzystując kognitywno-afektywny model osobowości, można bronić cnoty jako zespołu odpowiednich kognitywnych i afektywnych procesów, zakładających odpowiednie moralne przekonania i motywy oraz cnotliwego działania jako zespołu określonych „jeśli..., to”, behawioralnych sygnatur. Przy czym ,jeśli” oznacza konstrukt sytuacji, w której staje osoba cnotliwa, na przykład kogoś poproszonego o pomoc, a „to" sposób reagowania na nią. Właściwe reagowanie na taką sytuację zależy od wielu zmiennych - tego, kto prosi, kim jest osoba poproszona o pomoc, w jakich okolicznościach

23 P.B.M. VRanas, The Indeterminacy Paradox..., dz. cyt., s. I-42. 
pojawia się ta prośba. To odpowiada Arystotelesowskiemu działaniu cnotliwemu, które zawsze zakłada udział praktycznej mądrości (phronesis), co oznacza, że cnotliwym działaniom nie można przypisywać jednego określonego wzorca postępowania, ponieważ cnotliwe działanie jest zawsze mądrym działaniem, dopasowanym do sposobu postrzegania i rozumienia zaistniałej sytuacji. Sposób konstruowania sytuacji zależy m.in. od celów i wartości, które są przez sprawców cenione i realizowane w życiu, oraz wiedzy i doświadczenia, które pozwala odróżnić sytuację, gdy na przykład mamy do czynienia $z$ osobą, która rzeczywiście pomocy potrzebuje, od kogoś, kto po prostu chce kogoś oszukać i wykorzystać. Sposoby konstruowania sytuacji i odpowiedzi osób cnotliwych mogą być zatem postrzegane w sposób dyspozycjonalny, ale nie behawioralny tylko kognitywno-afektywny. To, w jaki sposób osoba cnotliwa odpowiada w działaniu na sytuację, w której została poproszona o pomoc (czy i w jaki sposób udzieli pomocy), zależy od sądu praktycznej mądrości, która wziąwszy pod uwagę wszelkie okoliczności, pozwoli podjąć najwłaściwszą decyzję.

\section{Obrona praktycznej madrości}

Kognitywno-afektywne ujęcie cnoty, w której bardzo ważną rolę pełni praktyczna mądrość, pozwala uniknąć krytyki sytuacjonistów, którzy podważali istnienie dyspozycji charakteru moralnego przez odwołanie do badań eksperymentalnych, skoncentrowanych na obserwacji zachowania badanych jedynie $z$ trzecioosobowej perspektywy. Sytuacjoniści, mając tego świadomość, rozpoczęli drugą fazę sporu o charakter cnoty, w której skupili się na podważaniu empirycznej adekwatności praktycznej mądrości. Na podstawie badań eksperymentalnych w obrębie psychologii kognitywnejgłównie eksperymentów przeprowadzonych przez Johna Bargha i jego współpracowników - próbowali pokazać, że ludzki sposób myślenia i zachowania nie zgadza się z założeniami Arystotelesowskiej praktycznej mądrości, której przypisuje się bardzo waż- 
ną deliberatywną funkcję. Mądry człowiek, według Arystotelesa, to nie tylko osoba inteligentna, bo ktoś taki może też być tylko zwykłym spryciarzem, ale dodatkowo taka osoba, która swą inteligencję wykorzystuje w dobrym moralnie celu. Sądy praktycznej mądrości o tym, co "tu i teraz” należy czynić, to takie sądy, które zawsze pozwalają na wybór najlepszego z punktu widzenia moralnego działania. Tak ujmowana phronesis - element etyki cnót o fundamentalnym znaczeniu - jest zdaniem sytuacjonistów empirycznie nieadekwatna, ponieważ większość ludzkich zachowań ma charakter automatyczny i dodatkowo zupełnie niezgodny $z$ przyjmowanym przez nas systemem wartości ${ }^{24}$.

Badania, na które powołują się sytuacjoniści, dotyczyły tzw. zjawiska torowania albo prymowania. Bargh w swoich eksperymentach pokazał, jak wielkie znaczenie w naszym poznaniu mają nieuświadomione czynniki sytuacyjne, które automatycznie, w nieuświadamiany sobie sposób, wpływają na nasz sposób zachowania. W prostych zadaniach, polegających na układaniu zdań $z$ rozsypanek wyrazowych, które zawierały odpowiednie treści (związane z uprzejmością albo nieuprzejmością), Bargh i jego współpracownicy zaobserwowali pewną prawidłowość. Te osoby, które układały zdania z wyrazów powiązanych $z$ uprzejmością, były bardziej cierpliwe i uprzejme w kolejnym etapie badania; w przypadku osób pracujących z wyrazami powiązanymi z nieuprzejmością było odwrotnie. Podobne badania przeprowadzono również $z$ wyrazami powiązanymi ze starością. Skutkiem wykonania takiego zadania było spowolnienie ruchów badanych, charakterystyczne dla osób starszych. Proces torowania wykorzystano także w badaniu uprzedzeń rasowych, które wykazało, że badani, pomimo deklaracji, które publicznie składali, gdy na ekranie komputera niepostrzeżenie pojawiał się obraz czarnoskórego mężczyzny, zachowywali się bardziej agresywnie niż w sytuacji, gdy na ekranie pojawiał się obraz białego mężczyzny. Gdy wszystkich badanych pytano o możliwe powody ich zachowania, żaden $z$ nich nie brał pod uwagę badanych czynników sytuacyjnych ${ }^{25}$.

24 M.W. Merritt, J.M. Doris, G. Harman, Character.., dz. cyt., s. 355-40I.

25 J.A. Bargh, M. Chen, L. Burrows, Automaticity of Social Behavior: Direct Effects of Trait Construct and Stereotype Activation on Action, "Journal of Personality and Social Psychology" 7I (I996), s. 233-235. Dokładne omówienie tych 
$\mathrm{Na}$ podstawie tych i wielu innych eksperymentów, które potwierdzały liczne typowe automatyczne procesy, którym się człowiek łatwo poddaje (jak np. efekt rozproszonej odpowiedzialności - gdy wielu ludzi jest świadkiem sytuacji, która wymaga pomocy, gotowość do pomocy gwałtownie spada, ponieważ podświadomie odczuwa się zwolnienie z odpowiedzialności reagowania, skoro wiele innych osób może udzielić pomocy, albo „efekt czystej ekspozycji" - wybierania opcji - osoby, przedmiotu, nazwy brzmiącej znajomo, choćby na rzecz tej opcji nie było żadnych innych racji), sytuacjoniści uznali, że działania oparte na sądach praktycznej mądrości właściwie nie występują w życiu. Ludzie na ogół podejmują zachowania automatycznie w sposób sobie nieuświadamiany, pod wpływem licznych sytuacyjnych czynników. Większość tych automatycznych procesów ma dodatkowo taki charakter, że gdybyśmy sobie je uświadomili (np. efekt rozproszonej odpowiedzialności), nie chcielibyśmy ich zaakceptować jako zasad naszego postępowania. Ta nieodpowiedniość deklarowanych wartości i automatycznych procesów, które odpowiadają za nasze zachowanie, jest - zdaniem sytuacjonistów - charakterystyczna dla człowieka, potwierdzona licznymi empirycznymi badaniami.

Obrona phronesis może także przebiegać na gruncie psychologii kognitywnej, w ramach której powstało wiele teorii funkcjonowania umysłu, bazujących na danych empirycznych, uwzględniających również wyniki eksperymentów, na które powołują się sytuacjoniści. Większość z tych teorii przyjmuje dwuprocesualny model funkcjonowania umysłu, w którym obok procesów automatycznych, opowiadających za bardzo poważną część naszych zachowań, istnieją także procesy refleksyjne, z którymi się człowiek bardziej utożsamia, choć stanowią one znacznie mniejszy procent aktywności jego umysłu. Jednak „mniejszy” nie oznacza zupełnie nieistotny. W dwuprocesualnych teoriach umysłu, na przykład w teorii Daniela Kahnemana, nie wyklucza się wpływania refleksyjnych funkcji umysłu na te automatyczne i odwrotnie. Sam Kahneman w swojej książce przestrzega przed gnuśnością

eksperymentów znajduje się w moim artykule Empiryczna adekwatność Arystotelesowskiej mądrości praktycznej, zamieszczonym w niniejszym tomie (s. 171-208). 
i zachęca do aktywizowania refleksyjnych funkcji umysłu. Pisze także, że należy docenić procesy automatyczne, ponieważ na ogół pozwalają nam bardzo dobrze funkcjonować w życiu codziennym ${ }^{26}$.

Również John Bargh nie wykorzystuje swoich badań do kwestionowania refleksyjnej funkcji umysłu. Jego prace zmierzają do pokazania, że prosty podział na funkcje automatyczne i refleksyjne jest dużym uproszczeniem, ponieważ te procesy zachodzą jednocześnie i mogą mieć bardzo różny charakter. Bargh wyróżnia wiele typów procesów automatycznych ${ }^{27}$, pozwalających bronić mądrości praktycznej, która - jak pisał Arystoteles - nie tylko spełnia funkcję deliberatywną, ale te ż jest rodzajem „widzenia” tego, co w konkretnej sytuacji należy uczynić. To widzenie można rozumieć jako moralną intuicję - uchwytywanie wprost tego, co tu i teraz jest moralnie dobre - która jest efektem bogatej wiedzy i uprzednio zdobytego doświadczenia w określonym zakresie. Wielu obrońców cnoty i etyki cnót porównuje cnotę do eksperckich umiejętności o charakterze praktycznym, których istnienia nikt nie kwestionuje. Wymagają one, podobnie jak cnoty, dobrego funkcjonowania obu typów procesów umysłowych, zarówno automatycznych, jak i refleksyjnych, oraz mają charakter globalnych dyspozycji ${ }^{28}$. Jeśli ktoś jest wirtuozem instrumentu, to potrafi zagrać bez względu na zmienne sytuacyjne, może to zrobić lepiej lub nieco gorzej, ale wykorzystywanie tej umiejętności nie jest zupełnie ograniczone wymogiem jakiegoś czynnika sytuacyjnego, którego niezachodzenie wiązałoby się $z$ niemożliwością działania (poza chorobą, kalectwem czy brakiem instrumentu).

26 D. Kahneman, Pułapki myślenia. O myśleniu szybkim i wolnym, tłum. P. Szymczak, Poznań 2012.

27 J.A. BARgh, Conditional Automaticity: Varieties of Automatic Influence in Social Perception and Cognition [w:] J.S. Uleman, J. Bargh (eds.), Unintended Thought, New York 1989, s. I0-28.

28 D. Narvaez, D.K. Lapsley, The Psychological Foundations of Everyday Morality and Moral Expertise [w:] D.K. Lapsley, C. Power (eds.), Character Psychology and Character Education, Notre Dame 2005, s. I50-I52; D. NArvaez, T. Bock, Developing Ethical Expertise and Moral Personalities [w:] L. Nucci, D. Narvaez, T. Krettenauer (eds.), Handbook of Moral and Character Education, New York 20I4, s. I40-I4I. Por. także artykuł Nancy Snow w niniejszym tomie (s. 35-72). 
Dyskusja na temat istnienia moralnego charakteru i cnoty etycznej nadal się toczy. Są realizowane wielkie projekty badawcze, skupiające filozofów, psychologów i teologów. Sytuacjoniści prowadzą badania w ramach The Moral Psychology Research Group, kierowanej przez Johna Dorisa. Christian Miller kieruje The Character Project, w ramach którego prowadzone są badania w obszarze psychologii, filozofii i teologii. Nancy Snow aktualnie realizuje The Self, Motivation and Virtue Project. Już dziś można powiedzieć, że filozofowie nie mogą uprawiać etyki w całkowitym oderwaniu od wyników badań nauk empirycznych. Muszą uważnie śledzić rozwój tych dyscyplin, które zajmują się kondycją ludzką, ponieważ ustanawianie ideałów, norm i obowiązków moralnych wymaga znajomości sposobu funkcjonowania człowieka w świecie w różnych obszarach. Konieczna jest znajomość psychologicznych i fizjologicznych aspektów procesów poznawczych, motywacji i działania, które składają się na ludzką kondycję. Zupełna autonomia etyki skazuje ją na izolację i tym samym na stagnację, która może skończyć się utratąjej praktycznego charakteru.

\section{Bibliografia}

Adams R., A Theory of Virtue: Excellence in Being for the Good, Oxford:

Oxford University Press, 2006.

Annas J., The Morality of Happiness, Oxford: Oxford University Press, 1993. Anscombe G.E., Modern Moral Philosophy, „Philosophy” 33 (I958), s. I-I9. Arystoteles, Etyka Nikomachejska, tłum. D. Gromska, Warszawa:

Wydawnictwo Naukowe PWN, 2007.

Audi R., Moral Knowledge and Ethical Character, Oxford-New York: Oxford University Press, I997.

Bargh J.A., Conditional Automaticity: Varieties of Automatic Influence in Social Perception and Cognition [w:] J.S. Uleman, J. Bargh (eds.), Unintended Thought, New York: Guilford, 1989, s. 3-5I.

Bargh J.A., Chen M., Burrows L., Automaticity of Social Behavior: Direct Effects of Trait Construct and Stereotype Activation on Action, "Journal of Personality and Social Psychology" 7I (1996), s. 230-244.

Darley J.M., Batson C.D., From Jerusalem to Jericho. A Study of Situational and Dispositional Variables in Helping Behavior, "Journal of Personality and Social Psychology" 27 (I973), s. I00-I08. 
Doris J.M., Lack of Character; Personality and Moral Behavior, Cambridge: Cambridge University Press, 2002.

Harman G., Moral Philosophy Meets Social Psychology: Virtue Ethics and the Fundamental Attribution Error, "Proceedings of the Aristotelian Society", New Series 99 (1999), s. 315-33I.

Harman G., No Character or Personality, „Business Ethics Quarterly” I3 (2003), s. 87-94.

Harman G., Skepticism about Character, „Ethics” I3 (2009), s. 235-242.

Hursthouse R., On Virtue Ethics, Oxford: Oxford University Press, I999.

Isen A.M., Levin P.F., Effect of Feeling Good on Helping: Cookies and Kindness, ,Journal of Personality and Social Psychology” 2I (1972), s. $384-388$.

Kahneman D., Pułapki myślenia. O myśleniu szybkim $i$ wolnym, tłum. P. Szymczak, Poznań: Media Rodzina, 2012.

Krahé B., Situation Cognition and Coherence in Personality: An Individual-Centred Approach, Cambridge: Cambridge University Press, 1990.

MacIntyre A., Dziedzictwo cnoty, tłum. A. Chmielewski, Warszawa: Wydawnictwo Naukowe PWN, 1996.

Merritt M.W., Aristotelian Virtue and the Interpersonal Aspect of Ethical Character, "Journal of Moral Philosophy" 6 (2009), s. 23-49.

Merritt M.W., Doris J.M., Harman G., Character [w:] J.M. Doris i in. (eds.), Moral Psychology Handbook, Oxford: Oxford University Press, 2010, s. 355-40I.

Milgram S., Posłuszeństwo wobec autorytetu, tłum. M. Hołda, Kraków: Wydawnictwo WAM, 2008.

Mischel W., Shoda Y., A Cognitive-Affective System Theory of Personality: Reconceptualizing the Invariances in Personality and the Role of Situations, „Psychological Review” I02 (I995)2, s. 246-268.

Narvaez D., Bock T., Developing Ethical Expertise and Moral Personalities [w: L. Nucci, D. Narvaez, T. Krettenauer (eds.), Handbook of Moral and Character Education, New York: Routledge, 2014, s. $140-158$.

Narvaez D., Lapsley D.K., The Psychological Foundations of Everyday Morality and Moral Expertise [w:] D.K. Lapsley, C. Power (eds.), Character Psychology and Character Education, Notre Dame: University of Notre Dame Press, 2005, s. I40-162.

Nussbaum M., The Fragility of Goodness: Luck and Ethics in Greek Tragedy and Philosophy, Oxford: Oxford University Press, 1986. 
Ross L., Nisbett R.E., The Person and the Situation. Perspectives of Social Psychology, New York: McGraw-Hill, I99I.

Russell D.C., Practical Intelligence and the Virtues, Oxford: Oxford University Press, 2009.

Sherman N., The Fabric of Character: Aristotle's Theory of Virtue, Oxford: Oxford University Press, 1989.

Sherman N., Making a Necessity of Virtue: Aristotle and Kant on Virtue, Cambridge: Cambridge University Press, 1997.

Shoda Y., Tiernan S.L., Mischel W., Personality as a Dynamical System: Emergence of Stability and Distinctiveness from Intra- and Interpersonal Interactions, „Personality and Social Psychology Review” 6 (2002), s. 316-325.

Slote M., Goods and Virtues, Oxford: Oxford University Press, I989. Slote M., From Morality to Virtue, Oxford: Oxford University Press, 1995.

Slote M., Morals from Motives, Oxford: Oxford University Press, $200 I$. Snow N., Virtue and the Social Intelligence. An Empirically Grounded Theory, New York: Routledge, 2010.

Swanton C., Virtue Ethics: A Pluralistic View, Oxford: Oxford University Press, 2003.

Szutta N., Status wspótczesnej etyki cnót, „Diametros - Internetowe Czasopismo Filozoficzne IF UJ" I (2004), s. 70-84.

Szutta N., Współczesna etyka cnót. Projekt nowej etyki?, Gdańsk: Wydawnictwo Uniwersytetu Gdańskiego, 2007.

Vranas P.B.M., Against Moral Character Evaluations: The Undetectability of Virtue and Vice, „Ethics” I3 (2009), s. 213-233.

Vranas P.B.M., The Indeterminacy Paradox: Character Evaluations and Human Psychology, „Nous” 39 (2005), s. I-42.

Walzer H., Sprawcy. Dlaczego zwykli ludzie dokonuja masowych mordów, tłum. M. Kurkowska, Warszawa: Wydawnictwo Naukowe Scholar, 20I0.

Zimbardo P., Efekt Lucyfera. Dlaczego dobrzy ludzie czynia zło?, tłum. A. Cybulko i in., Warszawa: Wydawnictwo Naukowe PWN, 2010.

Artykuł został napisany w ramach projektu badawczego finansowanego przez Narodowe Centrum Nauki (2011/oI/B/HSI/00522). 